\title{
THE EFFECT OF HEPARIN AND DICUMAROL ANTICOAGULANT THERAPY UPON THE ERYTHROCYTE SEDIMENTATION RATE
}

\author{
By STUART W. COSGRIFF \\ (From the Department of Medicine, College of Physicians and Surgeons, Columbia University, \\ and the Presbyterian Hospital, New York City)
}

(Received for publication February 27, 1948)

Anticoagulant therapy has been employed in thromboembolic disease with increasing frequency during the past few years. There has been a striking lack of unanimity in the literature (1 to 15) as to the effect of heparin or dicumarol per se upon the erythrocyte sedimentation rate. In view of the fact that anticoagulants are frequently employed in disorders in which the sedimentation rate is of importance in diagnosis as well as in judging their progress, definitive information concerning the effect of anticoagulants on the erythrocyte sedimentation rate would be of considerable practical value.

The sedimentation rate of heparinized blood has been reported to be greater than that of citrated or oxalated blood $(1,2)$. This has been ascribed not to an accelerating effect of heparin but rather to a stabilizing and retarding influence exerted by the oxalate and citrate salts upon the red blood cell sedimentation ( 1 to 5 ). Conflicting observations have been reported $(6,7)$ as regards the effect upon the citrated sedimentation rate when heparin was added in vitro to blood specimens. It has been noted $(5,8)$ that heparin in unusually large concentrations resulted in an acceleration of the sedimentation rate. Furthermore, during venous clotting time determinations in a patient receiving heparin therapy, it is a frequent observation that the plasma and cells of the blood of a well heparinized patient will separate more rapidly than usual in the clotting time test tubes. This phenomenon has been remarked on $(9,10)$ and has given the impression that in a patient receiving heparin therapy the sedimentation rate is quite briskly increased.

Previous observations as to the effect of dicumarol on the sedimentation rate also are not in accord (11 to 15). It has been reported (11) that the erythrocyte sedimentation rate is not elevated by dicumarol therapy per se. However, in several later communications (12 to 14 ) it was stated that the sedimentation rate was increased by dicumarol to such an extent that its reliability and depend- ability as a guide to healing was compromised. Recently one of these groups (15) has reversed its original stand (12) and stated that dicumarol probably has little, if any, effect on the sedimentation rate.

The present study was initiated to determine whether the sedimentation rate may still be accorded clinical significance in a patient who is receiving anticoagulant therapy.

\section{METHODS}

Venous clotting times were determined according to a modification of the Lee-White technique (16). Four chemically clean, $75 \times 10 \mathrm{~mm}$. test tubes, syringe and needle were rinsed with physiological saline solution. Following a cleanly negotiated venipuncture, 1 c.c. of blood was gently placed in each tube. Clotting was considered to have occurred when the blood did not flow when the tube was completely inverted and when there was no mixing of the red cell and plasma layers. Normal range was five to 12 minutes.

Prothrombin time determinations were performed on whole plasma, according to a modification (17) of Quick's technique (18) using 0.1 Molar sodium oxalate as the anticoagulant, commercially supplied rabbit lung as the source of thromboplastin, and 0.025 Molar calcium chloride. Normal prothrombin time in this laboratory with the technique employed was found to be $14( \pm 2)$ seconds. The per cent of normal prothrombin activity was determined from the saline dilution logarithmic prothrombin activity curve constructed according to Quick (18). By this technique, 14 seconds equals 100 per cent normal prothrombin activity, 22 seconds equals 30 per cent of normal prothrombin activity and $\mathbf{4 5}$ seconds equals 10 per cent of normal prothrombin activity.

The erythrocyte sedimentation rate was determined by the Westergren method (19), using 0.5 c.c. of 3.5 per cent sodium citrate as the anticoagulant for 2.5 c.c. of venous blood. The sedimentation rate was determined immediately in glass tubes of standard bore $(2.5-3.0 \mathrm{~mm}$.) with the blood column at the constant height of $200 \mathrm{~mm}$. and expressed as millimeters of fall in one hour. Normal values by this technique are considered to be less than $20 \mathrm{~mm}$. in one hour.

Technique of anticoagulant administration. Dicumarol was administered orally in the usual dosage of $300 \mathrm{mgm}$. on the first day, $200 \mathrm{mgm}$. on the second day and subsequent dosage depending on the result of the daily prothrombin time. Heparin sodium was administered intravenously in amounts of $50 \mathrm{mgm}$. ( 1 c.c. $=10 \mathrm{mgm}$.). 


\section{RESULTS}

The effects of the intravenous administration of $50 \mathrm{mgm}$. of heparin sodium were observed in ten subjects in whom the sedimentation rates had been static for a period of time before the start of the experiment. Sedimentation rates and venous clotting times were obtained immediately prior to the heparin injection, 30 minutes subsequent to the heparin injections and in some

TABLE I

The effect of the intravenous injection of $50 \mathrm{mgm}$. of heparin upon the erythrocyte sedimentation rate of ten subjects

\begin{tabular}{|c|c|c|c|c|c|c|c|}
\hline \multirow{2}{*}{ Case } & \multirow{2}{*}{ Determination } & \multicolumn{6}{|c|}{ Time in minutes after heparin } \\
\hline & & Control & 30 & 60 & 90 & 240 & 300 \\
\hline 1 & $\begin{array}{l}\text { V. C. T.* } \\
\text { E. S. R. } \dagger\end{array}$ & $\begin{array}{r}8 \\
25\end{array}$ & $\begin{array}{l}65 \\
20\end{array}$ & & $\begin{array}{l}55 \\
20\end{array}$ & $\begin{array}{r}9 \\
29\end{array}$ & - \\
\hline 2 & $\begin{array}{l}\text { V. C. T. } \\
\text { E. S. R. }\end{array}$ & $\begin{array}{l}8 \\
4\end{array}$ & $\begin{array}{r}50 \\
1\end{array}$ & & & $\begin{array}{r}16 \\
2\end{array}$ & 2 \\
\hline 3 & $\begin{array}{l}\text { V. C. T. } \\
\text { E. S. R. }\end{array}$ & $\begin{array}{r}9 \\
120\end{array}$ & $\begin{array}{l}113 \\
121\end{array}$ & & & & $\begin{array}{r}12 \\
122\end{array}$ \\
\hline 4 & $\begin{array}{l}\text { V. C. T. } \\
\text { E. S. R. }\end{array}$ & $\begin{array}{r}10 \\
2\end{array}$ & $\begin{array}{r}90 \\
3\end{array}$ & & & & $\begin{array}{l}8 \\
2\end{array}$ \\
\hline 5 & $\begin{array}{l}\text { V. C. T. } \\
\text { E. S. R. }\end{array}$ & $\begin{array}{r}17 \\
8\end{array}$ & $\begin{array}{r}91 \\
8\end{array}$ & & & & \\
\hline 6 & $\begin{array}{l}\text { V. C. T. } \\
\text { E. S. R. }\end{array}$ & $\begin{array}{l}18 \\
21\end{array}$ & $\begin{array}{r}143 \\
22\end{array}$ & & & & \\
\hline 7 & $\begin{array}{l}\text { V. C. T. } \\
\text { E. S. R. }\end{array}$ & $\begin{array}{l}15 \\
10\end{array}$ & $\begin{array}{r}113 \\
10\end{array}$ & & & & \\
\hline 8 & $\begin{array}{l}\text { V. C. T. } \\
\text { E. S. R. }\end{array}$ & $\begin{array}{l}14 \\
82\end{array}$ & $\begin{array}{r}107 \\
81\end{array}$ & & & & \\
\hline 9 & $\begin{array}{l}\text { V. C. T. } \\
\text { E. S. R. }\end{array}$ & $\begin{array}{l}20 \\
92\end{array}$ & $\begin{array}{l}110 \\
112\end{array}$ & & & & \\
\hline 10 & $\begin{array}{l}\text { V. C. T. } \\
\text { E. S. R. }\end{array}$ & $\begin{array}{r}20 \\
8\end{array}$ & $\begin{array}{r}220 \\
5\end{array}$ & & & & \\
\hline
\end{tabular}

${ }^{*} \mathrm{~V}$. C. $\mathrm{T} .=$ Venous clotting time in minutes.

$\dagger$ E. S. R. = Erythrocyte sedimentation rate in millimeters per hour.

instances at later intervals. The results are presented in Table I. It was observed that in amounts of heparin which prolong the venous clotting time to between 50 and 220 minutes the sedimentation rate remains relatively constant and is not significantly increased or decreased.

The effect of dicumarol on the sedimentation rate was determined in ten individuals with static sedimentation rates. Sedimentation rates and pro- thrombin times were determined prior to dicumarol administration and at intervals of one to three days during and subsequent to dicumarol therapy. The dicumarol was given as outlined in dosage sufficient to produce the degree of hypoprothrombinemia usually encountered during routine dicumarol anticoagulant therapy for thromboembolic disease. The results presented in Table II demonstrate that the sedimentation rate is not significantly altered and is remarkably constant during dicumarol administration.

It has been previously reported (20) that heparin and dicumarol are synergistic, in that the effect of heparin was enhanced by the concurrent administration of dicumarol. The effect of combined heparin and dicumarol administration upon the sedimentation rate was studied in five subjects, since it was felt that the concurrent administration of these anticoagulants possibly might be sufficient to alter the sedimentation rate. In these five individuals the sedimentation rate was not significantly altered by the preliminary administration of dicumarol at dosage levels sufficient to produce a marked hypoprothrombinemia. The injection of $50 \mathrm{mgm}$. of heparin sodium superimposed on the already established dicumarol prothrombin deficiency did not effect any significant change in the sedimentation rate, despite the production of marked changes in the venous clotting time.

\section{SUM MARY}

In the dosage employed clinically, heparin and dicumarol do not significantly alter the erythrocyte sedimentation rate.

The erythrocyte sedimentation rate of a patient receiving anticoagulant therapy can be considered to be as reliable a guide in the management of such an individual as it is in patients not receiving anticoagulants.

\section{BIBLIOGRAPHY}

1. Sappington, S. W., and Gillis, L. M., Heparin as the anticoagulant in sedimentation tests. Am. J. Clin. Path., 1941, 11, 83.

2. Enocksson, B., Gjertz, A., Schnell, A., and Torgersruud, $T$., The sedimentation reaction with heparin. Acta Med. Scandinav., 1936, 88, 455.

3. Plass, E. D., and Rourke, M. D., A new procedure for determining blood sedimentation rates. J. Clin. Invest., 1927-1928, 5, 531. 


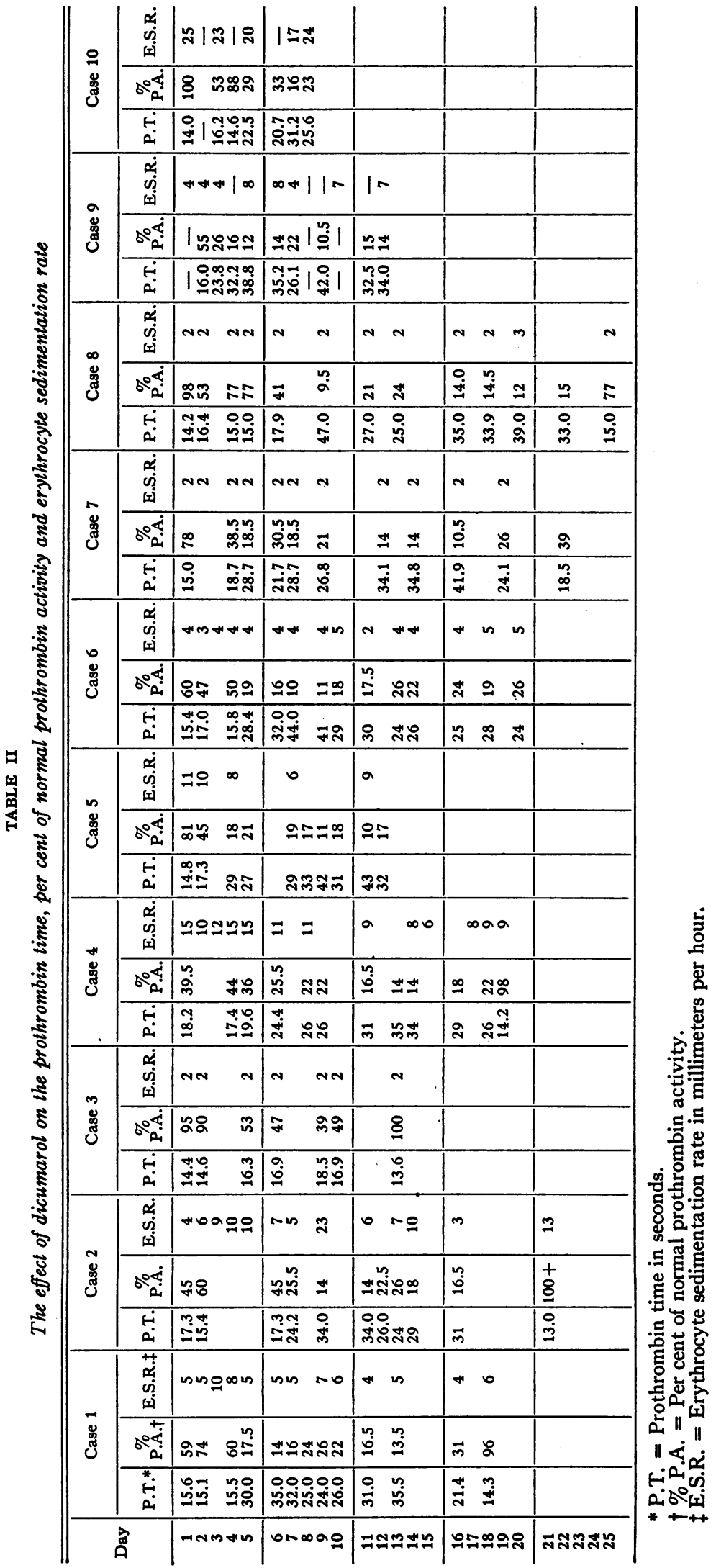


4. Rourke, M. D., and Plass, E. D., An investigation of various factors which affect the sedimentation rate of red blood cells. J. Clin. Invest., 1929, 7, 365.

5. Ham, T. H., and Curtis, F. C., On the sedimentation rate of erythrocytes; influence of technical, erythrocyte and plasma factors and quantitative comparison of 5 commonly used sedimentation methods. Medicine, 1938, 17, 447.

6. Strom, J., On the question of heparin or citrate for sedimentation reactions. Acta Med. Scandinav., 1938, 96, 365.

7. Nielson, G., Heparin and the blood sedimentation reaction. Acta Med. Scandinav., 1942, 111, 66.

8.' Jorpes, J. E., The origin and the physiology of heparin: the specific therapy in thrombosis. Ann. Int. Med., 1947, 27, 361.

9. Loewe, L., and Hirsch, E., Heparin in the treatment of thromboembolic disease. J. A. M. A., 1947, 133, 1263.

10. Loewe, L., Anticoagulation therapy with heparin/ Pitkin menstruum in thromboembolic disease. Am. J. Med., 1947, 3, 447.

11. Wright, I., and Prandoni, A., The dicoumarin $3,3^{\prime}-$ methylene-bis-(4-hydroxycoumarin); its pharmacologic and therapeutic action in man. J. A. M. A., 1942, 120, 1015.

12. Allen, E. V., Barker, N. W., and Waugh, J. M., A preparation from spoiled sweet clover which prolongs coagulation and prothrombin time of blood; clinical study. J. A. M. A., 1942, 120, 1009.

13. Peters, H. R., Guyther, J. R., and Brambel, C. E., Dicumarol in acute coronary thrombosis. J. A. M. A., 1946, 130, 398.

14. Falk, O. P. J., Treatment of coronary artery disease. Dicumarol therapy. J. A. M. A., 1947, 134, 491.

15. Barker, N. W., Hines, E. A., Kvale, W. F., and Allen, E. V., Dicumarol. Its action, clinical use and effectiveness as an anticoagulant drug. Am. J. Med., 1947, 3, 634.

16. Lee, R. I., and White, P. D., A clinical study of the coagulation time of blood. Am. J. M. Sc., 1913, 145, 495.

17. Shapiro, S., Sherwin, B., Redish, M., and Campbell, H. A., Prothrombin estimation; procedure and clinical interpretations. Proc. Soc. Exper. Biol. \& Med., 1942, 50, 85.

18. Quick, A. J., The nature of the bleeding in jaundice. J. A. M. A., 1938, 110, 1658.

19. Westergren, A., The technique of the red cell sedimentation reactions. Am. Rev. Tuberc., 1926, 14, 94.

20. Walker, J., and Rhoads, J. E., Effect of dicumarol on susceptibility to action of heparin. Surgery, 1944, 15, 859. 